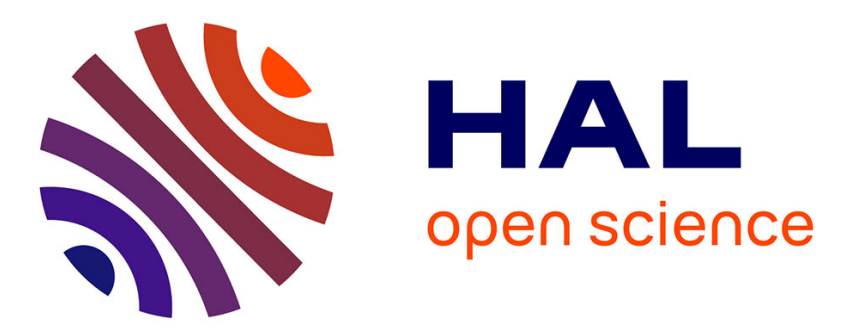

\title{
Definition of grassland biomes from phytoliths in West Africa
}

\author{
Laurent Bremond, Anne Alexandre, Odile Peyron, Joel Guiot
}

\section{To cite this version:}

Laurent Bremond, Anne Alexandre, Odile Peyron, Joel Guiot. Definition of grassland biomes from phytoliths in West Africa. Journal of Biogeography, 2008, 35 (11), pp.2039-2048. 10.1111/j.13652699.2008.01944.x . hal-01909598

\section{HAL Id: hal-01909598 \\ https://hal.science/hal-01909598}

Submitted on 17 Dec 2018

HAL is a multi-disciplinary open access archive for the deposit and dissemination of scientific research documents, whether they are published or not. The documents may come from teaching and research institutions in France or abroad, or from public or private research centers.
L'archive ouverte pluridisciplinaire $\mathbf{H A L}$, est destinée au dépôt et à la diffusion de documents scientifiques de niveau recherche, publiés ou non, émanant des établissements d'enseignement et de recherche français ou étrangers, des laboratoires publics ou privés. 


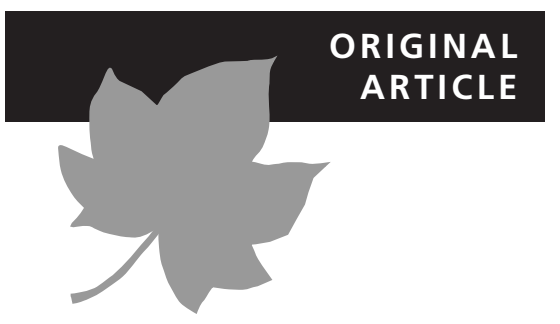

\title{
Definition of grassland biomes from phytoliths in West Africa
}

\author{
Laurent Bremond ${ }^{1,2 \star}$, Anne Alexandre ${ }^{1}$, Odile Peyron ${ }^{3}$ and Joël Guiot ${ }^{1}$
}

${ }^{1}$ Centre Européen de Recherche et

d'Enseignement des Géosciences de

l'Environnement (CEREGE), Université Paul

Cézanne Aix-Marseille (UPCAM), Unité

Mixte de Recherche (UMR) 6635, Centre

National de la Recherche Scientifique (CNRS),

Europôle Méditerranéen de l'Arbois, Aix-

en-Provence, France, ${ }^{2}$ Centre de Bio-

Archéologie et d'Écologie (CBAE), Ecole

Pratique des Hautes Études (EPHE),

Université de Montpellier 2, UMR 5059 CNRS,

Montpellier, France and ${ }^{3}$ Laboratoire de

Chrono-Écologie, Université de Franche-

Comté, UMR 6565 CNRS, UFR Sciences et

Techniques, Besançon, France
${ }^{\star}$ Correspondence: Laurent Bremond, CBAE, Institut de Botanique, 163 rue Broussonet, F-34090 Montpellier, France.

E-mail: laurent.bremond@univ-montp2.fr

\begin{abstract}
Aim In order to enhance the effectiveness of comparisons between modelled and empirical data for present and past vegetation, it is important to improve the characterization of tropical grass-dominated biomes reconstructed from fossil tracers. This study presents a method for assigning phytolith assemblages to tropical grass-dominated biomes, with the objective of offering a new tool for combining pollen and phytolith data in the reconstruction of tropical biomes.
\end{abstract}

Location The West African latitudinal transect studied here extends from $12^{\circ} \mathrm{N}$ (southern Senegal) to $23^{\circ} \mathrm{N}$ (southern Mauritania), passing through the Guinean, Sudanian, Sahelian and Saharan bioclimatic zones.

Methods Modern phytolith assemblages were extracted from 59 soil surface samples taken throughout the study area and allocated, a priori, to three current biomes: (1) desert $\mathrm{C}_{4}$ grassland, (2) short grass savanna, and (3) tall grass savanna. Five out of nine phytolith types identified were used as predictors in a discriminant analysis (with calibration and validation steps) for assigning phytolith assemblages to biomes. In addition, 74 modern pollen spectra from the West African transect, acquired from the African Pollen Database (http://medias.obs-mip.fr/apd), were processed by the biomization method. This mathematical procedure involves assigning palynological taxa to one or more plant functional types, which represent broad classes of plants. The plant functional types, in turn, are combined to define biomes following a specific set of algorithms and rules. The resulting maps of the phytolith biomes thus derived were compared with maps of pollen biomes and of contemporary ecosystem classes.

Results In the calibration and validation steps, $91.5 \%$ and up to $83 \%$, respectively, of the phytolith samples were assigned to the correct biome. The short grass savanna and tall grass savanna biomes were assigned with similar accuracy by both the phytolith and pollen biomization methods, but the phytolith method gave substantially superior results for the desert $\mathrm{C}_{4}$ grassland biome, providing seven out of seven correct assignments, compared with just one out of four by pollen biomization. Comparisons between an existing ecosystem map and the maps created from phytolith estimation showed close correspondence for desert $\mathrm{C}_{4}$ grassland, short grass savanna and tall grass savanna, the latter providing correct assignments in 88,62 and $91 \%$ of cases, respectively.

Main conclusions The phytolith discriminant analysis method presented here accurately estimates three $\mathrm{C}_{4}$ grass-dominated biomes that are widespread in West Africa. Complementarities between the phytolith method and pollen biomization are highlighted. Combining complementary phytolith and pollen data would provide more accurate assignments of $\mathrm{C}_{4}$ grass-dominated biomes than pollen biomization alone.

\section{Keywords}

Arid environments, biome, $\mathrm{C}_{4}$ grasses, classification, grassland, phytolith, pollen, tropical grassland, West Africa. 


\section{INTRODUCTION}

Global vegetation models provide a means for translating the outputs from climate models into maps of potential vegetation distribution in present, past and future climate scenarios (Prentice et al., 1992; Haxeltine \& Prentice, 1996). One type of output from such models is assignment to biomes, which may be defined as macro-scale landscape types classified according to the predominant vegetation characterized by its adaptation to the corresponding environment (Campbell, 1996). The simplest vegetation models are based on bioclimatic indicators linked to climatic variables affecting specific aspects of plant growth or survival. These indicators, when appropriately selected, can be used to estimate the locations and potential shifts of biome limits in response to past or future climate changes (Cramer, 2002). Thus, biome models can be coupled with climatic models to estimate the distribution of past biomes (Prentice et al., 1992). The validity of these simulations may be assessed by comparisons with the distribution of biomes reconstructed from proxy data. To this end, the biomization method (Prentice et al., 1996, 2000) reconstructs biomes from pollen data by assigning pollen taxa to one or more plant functional types (PFTs; broad classes of plants defined by stature, leaf form, phenology and bioclimatic factors) and by considering biomes as combinations of several PFTs (Jolly et al., 1998). This method has proven very efficient for the reconstruction of forest biomes. However, in the absence of precise pollen identification of Poaceae species and subfamilies, grass-dominated biomes, which are the most widespread modern continental biomes (Bond et al., 2005), are not accurately characterized by pollen data. For instance, the two steppic PFTs (warm grasses/shrubs and cool grasses/ shrubs) defined by Prentice et al. (1992), although distinguished in Europe (Tarasov et al., 1999), cannot be reconstructed properly in the intertropical area from modern pollen data (Jolly et al., 1998). Samples collected in the steppe biome (dry tropical grassland) are often incorrectly assigned by the biomization method to the savanna biome (wet tropical grassland), the tropical xerophytic woods/scrub biome or the temperate xerophytic woods/scrub biome (Jolly et al., 1998). This lack of precision is a cause of particular concern when attempting to reconstruct vegetation during the last glacial period, when grass-dominated biomes were even more widespread than at present.

One potentially useful method for reconstructing grassland biomes is based on analysis of phytoliths, amorphous silica particles that precipitate in and/or between the cells of living plant tissues. Because of redundancy and multiplicity in phytolith production (Fredlund \& Tieszen, 1994), often one phytolith type cannot be related to one plant taxon. However, at a broader level, there are several notable advantages in the use of phytolith assemblages for reconstructing vegetation types, particularly for estimating biomes. Phytolith assemblages can be used successfully to discriminate current intertropical grassland types and forests of low elevation, through variations in phytolith type abundances associated with variations in dominant grass subfamilies and tree-cover density (Bremond et al., 2005a, 2008; Barboni et al., 2007). Several authors (e.g. Alexandre et al., 1997; Scott, 2002; Abrantes, 2003) have also reconstructed paleovegetation changes in the intertropical area using fossil phytolith assemblages. In addition, recent studies present quantitative calibration of the relationships between intertropical grass phytolith assemblages and climatic parameters (Prebble et al., 2002; Bremond et al., 2005b; Lu et al., 2006). Results of these studies suggest that, as fossil phytolith remains are recoverable in significant quantities from various kinds of soil, as well as marine and continental sediments, phytolith analyses could make significant contributions to the accurate reconstruction of global grassland types and their related bioclimatic constraints. Furthermore, the complementary use of phytolith and pollen data (the latter being most efficient for reconstructing forest types) could offer interesting opportunities for developing a better understanding of global vegetation and climate dynamics.

The objective of the study presented here was to develop a new tool for combining pollen and phytolith data in the analysis of vegetation in intertropical areas. We present a discriminant analysis procedure that allows biomes estimated from modern phytolith data to be compared with those estimated from pollen data using the biomization method (Prentice et al., 1992). Consistencies and inconsistencies between the biomes indicated by the two methods are discussed, and an attempt is made to evaluate estimated West African vegetation types with respect to the ecosystem groups described by Olson (1994a,b).

\section{MATERIALS AND METHODS}

The West African latitudinal transect studied here ranges between $12^{\circ} \mathrm{N}$ (southern Senegal) and $23^{\circ} \mathrm{N}$ (southern Mauritania). The climatic zoning (Table 1) is characterized from south to north by a decrease in mean annual rainfall from 1300 to $100 \mathrm{~mm}$ and a concomitant increase in the duration of the dry season from 5 to $>9$ months. The mean temperature of the coldest month ranges from $19^{\circ} \mathrm{C}$ in the south to $25^{\circ} \mathrm{C}$ in the north, and the mean temperature of the warmest month is between 30 and $31^{\circ} \mathrm{C}$ throughout the study area.

The sampled transect passes through four vegetation zones (Fig. 1): the Guinean, Sudanian, Sahelian and Saharan zones. Table 1 presents, for each zone, a description of the vegetation physiognomy after White (1983); a summary of the dominant grass subfamilies after Wyk (1979), Lézine (1987) and Le Houérou (1993); and associated climatic boundaries after Leemans \& Cramer (1991) and the Office Météo du Sénégal (Centre de Suivi Ecologique, 2000). On the basis of this information, three current biomes have been outlined (Table 1): (1) the desert $\mathrm{C}_{4}$ grassland biome, characteristic of the Saharan zone, dominated by shrub and short grass savannas with annual and perennial $\mathrm{C}_{4}$ grasses; (2) the short grass savanna biome, characteristic of the Sahelian zone, composed of shrub and tree grass savannas dominated by 
Phytolith biomes for West Africa

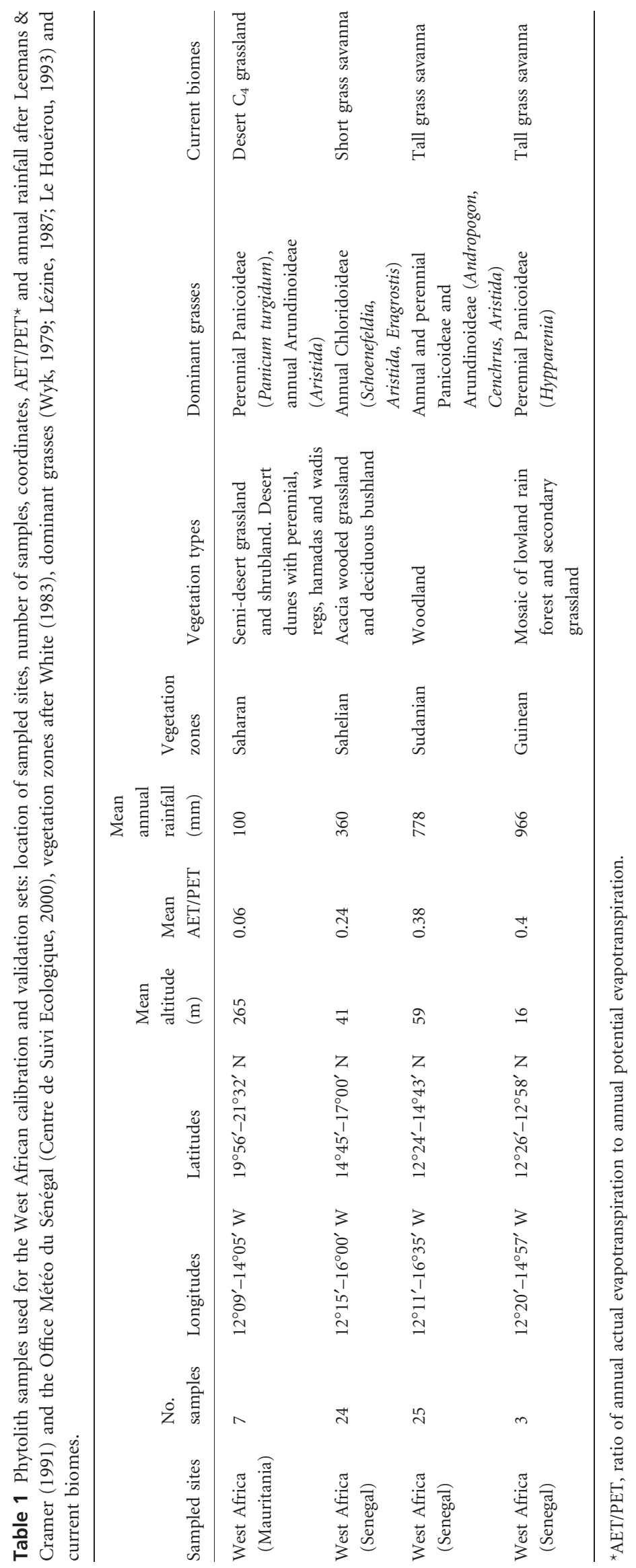




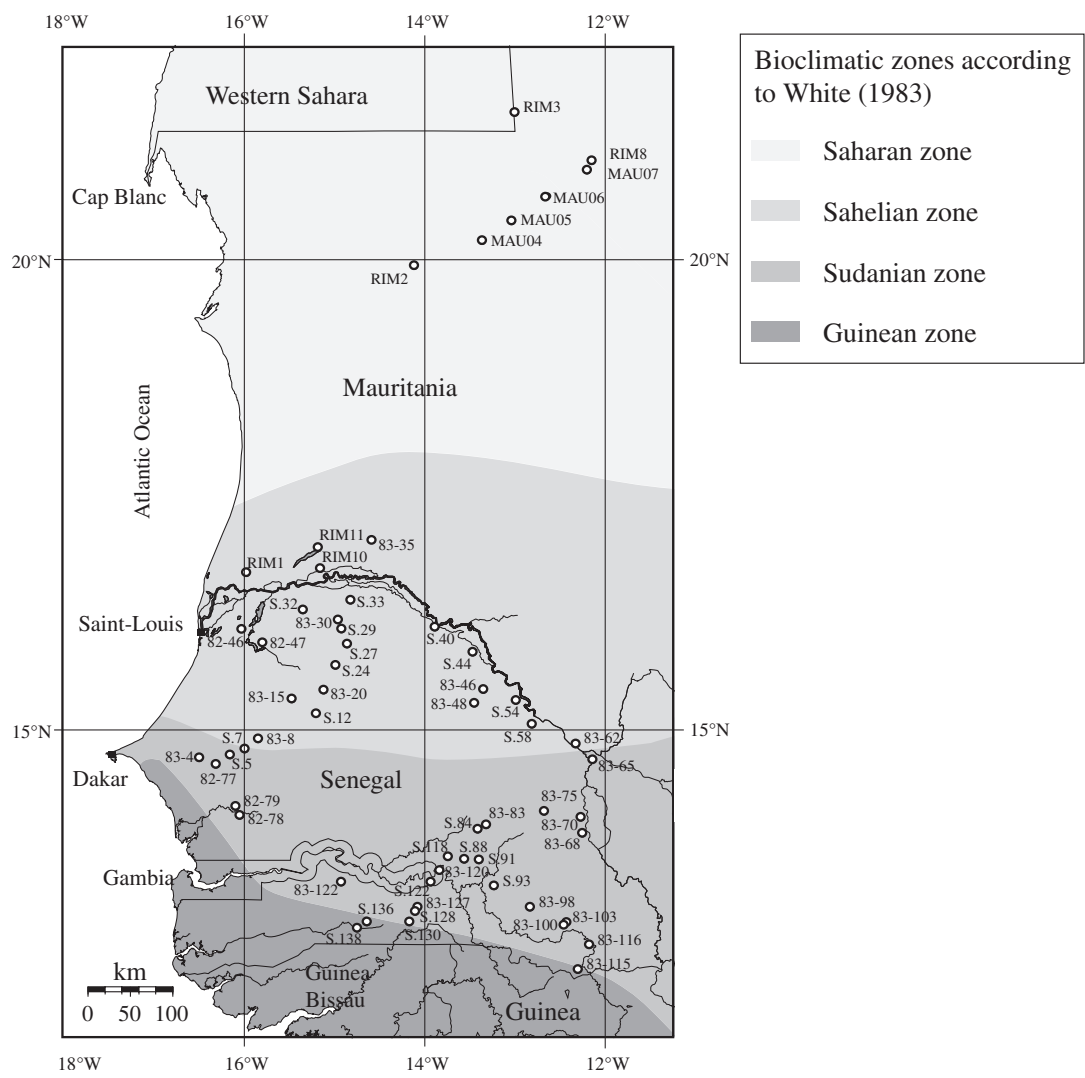

Figure 1 Location of the sampled sites across four bioclimatic zones in West Africa (after White, 1983). annual $\mathrm{C}_{4}$ grasses; and (3) the tall grass savanna biome, widespread in the Sudanian and Northern Guinean zones, consisting of both woodlands and tree and tall grass savannas dominated by perennial $\mathrm{C}_{4}$ grasses.

\section{Phytoliths}

Modern phytolith assemblages were extracted from soil surface samples collected from 59 sites between 1987 and 1995 (Lézine et al., 1995) in various vegetation zones and current biomes in West Africa (Fig. 1; Table 1). At each site, individual subsamples were collected randomly over $100 \mathrm{~m}^{2}$ from the humic horizon when present, or from the surface of the regolith in dry areas. In all cases, the litter was removed from the sampled material.

The method used for extracting phytoliths (following Kelly, 1990) involved: (1) grinding, (2) dissolution of carbonates, (3) reduction and removal of iron oxides, (4) oxidation of organic matter, (5) sieving at $60 \mu \mathrm{m}$, checking for the absence of phytoliths in the $>60 \mu \mathrm{m}$ fraction, (6) removal of clay, and (7) densimetric separation of phytoliths in a dense solution of $\mathrm{ZnBr}_{2}(d=2.3)$.

Phytolith assemblages, based on the relative abundances of nine phytolith types in each sample, have been described by Bremond et al. (2005b). Nine types of phytolith were counted in the assemblages and, of these, five were used as predictors in a discriminant analysis in order to assign each phytolith assemblage to its biome of origin. These five phytolith types were selected, a priori, as their relative abundance in the assemblages reflected a vegetation characteristic (Bremond et al., 2005b) that could be used to discriminate between phytolith biomes. The terms used follow the International Code for Phytolith Nomenclature (ICPN) according to Madella et al. (2005), and common names previously used by Bremond et al. (2005b) are given in brackets. The five selected phytolith types were: (1) Globular granulate (rough spherical), (2) parallelepipedal and cuneiform bulliform cells (fan-shaped), (3) bilobate short cell (dumbbell), (4) cross, and (5) saddle. Type 1 is produced by the wood of tropical trees and shrubs (Kondo et al., 1994), and its abundance (relative to that of short cells' phytoliths from grasses) reflects the density of tree cover (Bremond et al., 2005a; Barboni et al., 2007). Type 2 is produced in the bulliform cells of grasses. The outer epidermal walls of these cells contract when the leaf is dehydrated (due to increases in transpiration and/or the duration of water stress), promoting leaf-rolling (O'Toole \& Cruz, 1980; Hsiao et al., 1984). This, in turn, leads to silica saturation and precipitation. The more grasses transpire and/ or suffer water stress, the more silicified bulliform cells they produce (Bremond et al., 2005b). Types 3 and 4 occur primarily in the Panicoideae subfamily (Twiss et al., 1969; Mulholland, 1989; Fredlund \& Tieszen, 1994; Kondo et al., 1994), which is dominated by tall $\mathrm{C}_{4}$ grasses adapted to warm climates in sites with readily available soil moisture (Sage et al., 1999). Type 5 is relatively abundant in the Chloridoideae grass subfamily (Twiss et al., 1969; Mulholland, 1989; Fredlund \& 
Tieszen, 1994; Kondo et al., 1994), a group of short $\mathrm{C}_{4}$ grasses adapted to warm and dry climates at sites with little available soil moisture (Sage et al., 1999).

The following four phytolith types, although components of the phytolith assemblages, were excluded from the discriminant analysis for the reasons outlined below. First, the papillae cell (ICPN name) or cone-shaped (Bremond et al., 2005b) type is characteristic of Cyperaceae (sedges) (Kondo et al., 1994; Wallis, 2003). However, because this type fragments and dissolves rapidly, its relative abundance in soils and sediments is not proportional to the abundance of sedges (Alexandre et al., 1997). Second, the globular psilate (ICPN name) or smooth spherical (Bremond et al., 2005b). This type appears to have several origins (Kondo et al., 1994; Piperno, 2006), and has no clear taxonomic significance. Third, the globular echinate (ICPN name) or crenate spherical (Bremond et al., 2005b) is produced by Palmae (Piperno, 2006). However, as palms can be adapted to various climatic conditions, this type is not helpful for distinguishing among intertropical biomes. Fourth, the acicular hair cell (ICPN name) or point-shaped (in Bremond et al., 2005b) type is produced by all the grasses, and no relationship has been demonstrated between its relative abundance and either climate or vegetation parameters.

After allocating, a priori, each of the 59 phytolith assemblages to one of the three current biomes previously outlined (Table 1), a factorial discriminant analysis (Venables \& Ripley, 2002) was run using the five phytolith types as predictors to assign one of the three biomes as a result of a discriminant linear function. In this (calibration) step, the resulting biomes were referred to as phytolith biomes. The discriminant linear functions were characterized by coefficients associated with the five phytolith variables. Each coefficient was calculated to minimize the variance of the samples (phytolith assemblages) within groups (phytolith biomes) and to maximize the variance between the group centroids.

The validity of the discriminant analysis was checked through bootstrapping analysis with 100 iterations (validation step) using the function 'lda' provided by the $\mathrm{R}$ software (http://www.r-project.org). The data set, comprising 59 assemblages, was randomly sampled. The sampled observations were then used to recalibrate the discriminant functions, while the remaining observations were used to verify them. Percentages and confidence intervals of well classified dependent and independent observations were calculated, and the results presented as 2.5th, 50th and 97.5th percentiles.

\section{Pollen}

Seventy-four modern pollen spectra from the West African study area (for details see Peyron, 1999) were accessed online through the African Pollen Database (http://medias.obs-mip. fr/apd) and assigned to pollen biomes using the biomization method (Prentice et al., 1996), which classifies the plant taxa represented in pollen assemblages into a small number of PFTs. As a biome is defined as a combination of PFTs potentially present within it (Prentice et al., 1992), it is possible to construct a taxon vs. biome matrix indicating which taxa may occur in which biome(s). This matrix can then be used to calculate affinity values between each pollen assemblage and each biome. The biome assigned is the one with the highest affinity value. In this study, assigned pollen biomes were identified using PPPbase software (Goeury \& Guiot, 1996), which generates affinity scores for PFTs for each pollen assemblage. The calculation is based on the sum of the square roots of pollen percentages using all the pollen grains (excluding aquatics, ferns and exotic taxa) present in the pollen assemblages. The sum of the scores of the PFTs included in each biome provides a biome score. Lastly, a biome is assigned according to the highest affinity score obtained at each site. This biomization method was applied to African pollen data first by Jolly et al. (1998) and later by Peyron et al. (2000) and Vincens et al. (2006).

\section{RESULTS}

\section{Phytolith biomes}

\section{Calibration step}

Table 2 presents the coefficients calculated for the five phytolith types and for each of the three discriminant functions (one per phytolith biome). Assemblages were correctly assigned to biomes for 54 out of 59 samples $(91.5 \%$ correct assignments). However, the five erroneous assignments need to be explained. Edaphic conditions may, at a local scale, control the intensity of water stress and the distributions of grass subfamilies (which may differ from their regional distributions). Samples RIM 1 and 82-47 (Fig. 1), belonging to the short grass savanna biome but assigned to the tall grass savanna biome, may actually represent a local predominance of Panicoideae (tall) grasses in contrast to the zonal dominance of Chloridoideae (short) grasses. For example, the 82-47 sampling site is located in the Ferlo river valley, where humid

Table 2 Results of the discriminant analysis run for the 59 phytolith assemblages (calibration step).

\begin{tabular}{|c|c|c|c|}
\hline Current biomes & $\begin{array}{l}\text { Desert } \mathrm{C}_{4} \\
\text { grassland }\end{array}$ & $\begin{array}{l}\text { Short grass } \\
\text { savanna }\end{array}$ & $\begin{array}{l}\text { Tall grass } \\
\text { savanna }\end{array}$ \\
\hline $\begin{array}{l}\text { Variables } \\
\text { (phytolith types) }\end{array}$ & $(12 \%)$ & $(41 \%)$ & $(47 \%)$ \\
\hline Globular granulate & 3.1713 & 3.739 & 3.949 \\
\hline $\begin{array}{l}\text { Parallepipedal and } \\
\text { cuneiform } \\
\text { bulliform cells }\end{array}$ & 3.5291 & 3.915 & 3.915 \\
\hline Bilobate short cell & 2.2149 & 2.527 & 2.649 \\
\hline Cross & 2.8684 & 3.277 & 3.676 \\
\hline Saddle & 2.5961 & 3.366 & 2.834 \\
\hline Constant & -96.1819 & -125.038 & -126.996 \\
\hline
\end{tabular}

Coefficients are calculated for the five phytolith types and for each of the three discriminant functions (one per phytolith biome). Percentages represent the proportions of samples per current biome. 
edaphic conditions may have favoured the local predominance of tall grasses in the riparian vegetation. In contrast, S7 (Fig. 1) was assigned to the desert $\mathrm{C}_{4}$ grassland biome rather than the tall grass savanna biome, on account of the high proportion of parallelepipedal and cuneiform bulliform cells in the assemblage, while S-136 (Fig. 1) was assigned to the short grass savanna biome instead of the tall grass savanna biome. These samples may have originated from a grassy patch that was subject to high local water stress and/or high transpiration rates. Furthermore, erroneous assignments may be related to the location of some sampling sites in the transition area between two bioclimatic zones. While the boundaries between the different zones in this study are defined according to White (1983), transition areas represent a macro-scale continuum of grassland types, and some samples obtained from these areas may have been assigned incorrectly. For instance, S5 (Fig. 1), located at the transition of the Sudanian and Sahelian zones, may have been wrongly defined as part of the tall grass savanna biome.

\section{Validation step}

The results of the bootstrapping analysis are summarized in Table 3. The first matrix presents the classification of the samples (as percentages) for the new calibration set, while the second presents the independent verification set after bootstrapping. The results of this validation step support those obtained by the calibration step: $92.5 \%$ (95\% confidence interval $(\mathrm{CI})=83,98.4)$ of the calibration samples and up to $83.1 \%(95 \% \mathrm{CI}=68.8,95)$ of the verification samples were correctly assigned to biomes.

\section{Comparison between estimated phytolith and pollen biomes}

Maps of pollen and phytolith biomes, estimated for the West African samples, are displayed in Fig. 2. The seven samples from the Saharan zone were accurately assigned to the phytolith desert $\mathrm{C}_{4}$ grassland biome by the phytolith method, whereas three of the four samples from the desert biome were erroneously assigned to the steppe biome by the pollen biomization method. Twenty-two of 24 samples from the Sahelian zone were correctly assigned to the short grass savanna biome by the phytolith method, while 27 of the 34 samples were correctly assigned to the steppe biome by pollen biomization. Samples from the Sudanian zone or the northern Guinean zone were mainly correctly assigned either to the tall grass savanna biome by the phytolith method ( 25 out of 28 samples) or to the savanna biome and tropical xerophytic woods/scrub biome by the pollen biomization (20 and 8, respectively, out of the 34 samples).

\section{DISCUSSION}

\section{Comparison between estimated phytolith biomes and contemporary ecosystem classes}

The Global Land Cover Characteristics Database, derived from satellite data (Loveland et al., 2000; http://edcdaac.usgs.gov/ glcc/af_int.html), provides the basis for several thematic maps including Olson's (1994a,b) Global Ecosystems maps. Comparisons between biome maps estimated by pollen biomization and the Global Ecosystems maps have frequently been made (Jolly et al., 1998; Hély et al., 2006; Vincens et al., 2006). In this study, in order to confirm that the phytolith method was adequate for characterizing present West African vegetation types, the phytolith sites were projected onto the West African section of the Global Ecosystems map using MapInfo software (Fig 2c). Table 4 displays the quantitative results of this projection, confirming that the distribution of the desert $\mathrm{C}_{4}$ grassland phytolith biome was in close agreement with the occurrence of bare desert ( $88 \%$ correct assignments). The short grass savanna phytolith biome corresponded to the combined distributions of hot and mild grasses and shrubs

Table 3 Validity of the discriminant analysis checked through bootstrapping analysis with 100 iterations (validation step).

\begin{tabular}{|c|c|c|c|c|c|c|c|c|c|}
\hline \multirow[b]{2}{*}{ Current biomes } & \multicolumn{3}{|c|}{ Phytolith biomes } & \multicolumn{3}{|c|}{ Well classified Phytolith biomes } & \multicolumn{3}{|c|}{$\begin{array}{l}\text { Total of well classified } \\
\text { Phytolith biomes }\end{array}$} \\
\hline & $\begin{array}{l}\text { Desert } C_{4} \\
\text { grassland }\end{array}$ & $\begin{array}{l}\text { Short grass } \\
\text { savanna }\end{array}$ & $\begin{array}{l}\text { Tall grass } \\
\text { savanna }\end{array}$ & 2.5 th & 50th & 97.5 th $\dagger$ & 2.5 th & 50 th & 97.5 th \\
\hline \multicolumn{10}{|l|}{ Calibration } \\
\hline Desert $\mathrm{C}_{4}$ grassland & 100 & 0 & 0 & 66.7 & 100 & 100 & & & \\
\hline Short grass savanna & 0 & 92 & 8 & 78.5 & 94.4 & 100 & 83 & 92.5 & 98.4 \\
\hline Tall grass savanna & 3 & 7 & 90 & 78.9 & 91.7 & 100 & & & \\
\hline \multicolumn{10}{|l|}{ Verification } \\
\hline Desert $\mathrm{C}_{4}$ grassland & 86 & 14 & 0 & 50 & 100 & 100 & & & \\
\hline Short grass savanna & 8 & 79 & 13 & 50 & 78.9 & 100 & 68.8 & 83.1 & 95 \\
\hline Tall grass savanna & 4 & 11 & 86 & 65.1 & 84 & 100 & & & \\
\hline
\end{tabular}

Percentages of well classified phytolith assemblages (phytolith biomes) were obtained after calibrating and verifying the discriminant functions. ${ }^{*}$ Calculated for each bootstrap simulation by summing the number of well classified observations in each group (taking into account the group's size). $\dagger 2.5$ th, 50th and 97.5th percentiles (median and 95\% CI) are deduced from the vector summing the well classified simulated observations. 

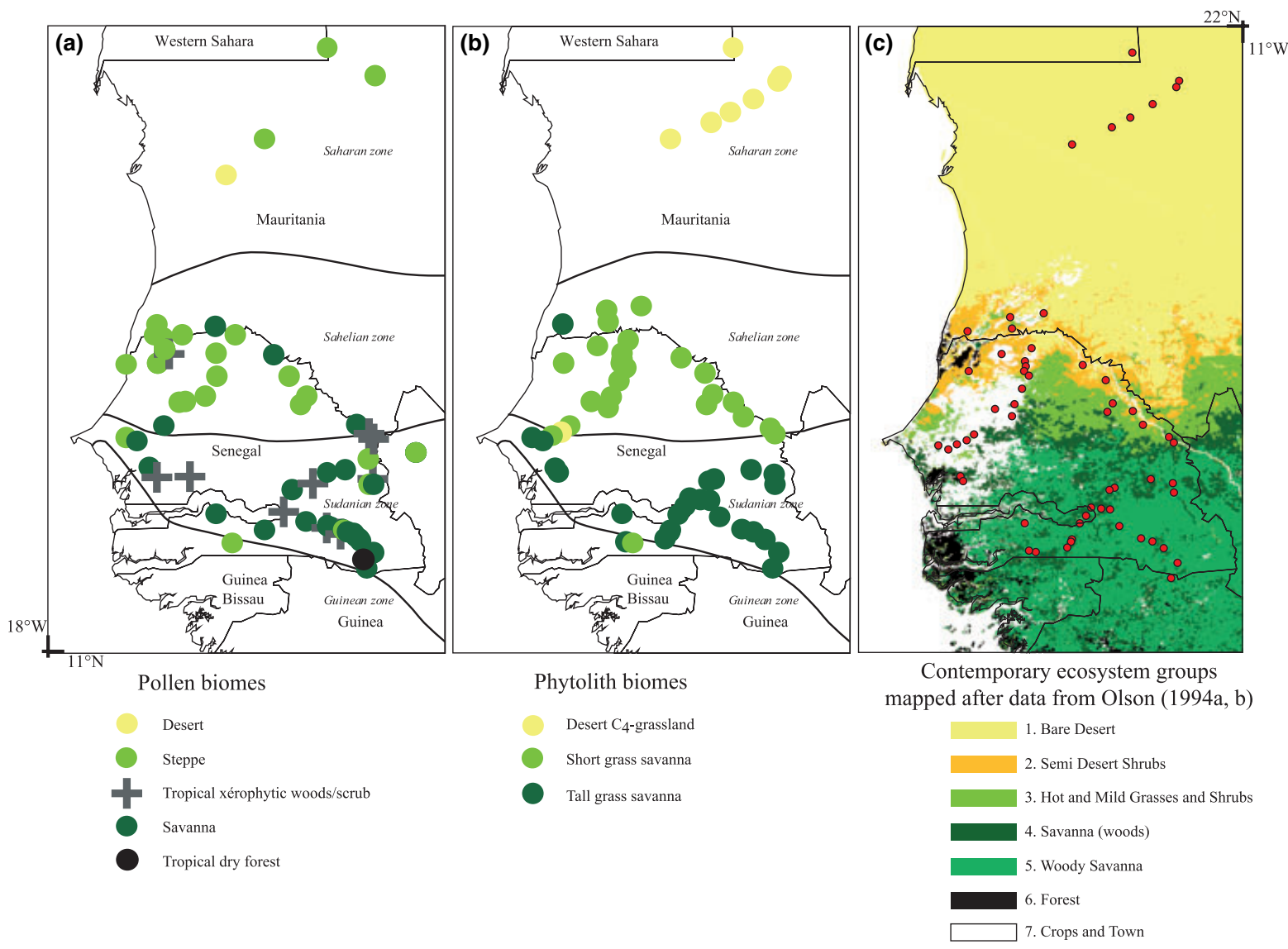

Figure 2 (a) Assignment of the samples to pollen biomes (Peyron et al., 2000). (b) Assignment of the samples to phytolith biomes (this study). (c) Contemporary ecosystem classes, modified after Olson (1994a,b). Olson's ecosystem classes (16 in this study area) were combined and reduced to seven groups representing more than $94 \%$ of the area.

Table 4 Quantitative results of the projection of the 59 sites for which phytolith biomes were estimated onto the ecosystem map derived from Olson (1994a,b).

\begin{tabular}{|c|c|c|c|c|c|c|c|c|c|}
\hline Phytolith biomes & $\begin{array}{l}\text { Bare } \\
\text { desert }\end{array}$ & $\begin{array}{l}\text { Hot and } \\
\text { mild grasses } \\
\text { and shrubs }\end{array}$ & $\begin{array}{l}\text { Semi-desert } \\
\text { shrub }\end{array}$ & $\begin{array}{l}\text { Woody } \\
\text { savanna }\end{array}$ & $\begin{array}{l}\text { Savanna } \\
\text { (woods) }\end{array}$ & Mangrove & $\begin{array}{l}\text { Broadleaf } \\
\text { crops }\end{array}$ & $\begin{array}{l}\text { Crops } \\
\text { and } \\
\text { town }\end{array}$ & $\begin{array}{l}\text { Inland } \\
\text { water }\end{array}$ \\
\hline Desert $\mathrm{C}_{4}$ grassland & 88 & 1 & 0 & 0 & 0 & 0 & 11 & 0 & 0 \\
\hline Short grass savanna & 13 & 35 & 27 & 4 & 6 & 0 & 8 & 5 & 3 \\
\hline Tall grass savanna & 0 & 1 & 4 & 56 & 35 & 1 & 3 & 0 & 0 \\
\hline
\end{tabular}

For each site, consideration was given to the ecosystem class represented in the grid cell $\left(1 \times 1 \mathrm{~km}^{2}\right)$ in which it is located, as well as the ecosystem class from the contiguous cells $\left(3 \times 3 \mathrm{~km}^{2}\right)$, in order to take into account the imprecision of some site coordinates. Values are percentages of grid cells of each ecosystem class in each estimated phytolith biome.

and semi-desert shrub (62\% correct assignments), while the tall grass savanna phytolith biome corresponded closely to the occurrence of woody savanna and savanna (woods) (91\% correct assignments).

\section{Comparisons between the phytolith method and pollen biomization}

The pollen biomization method was relatively unreliable for characterizing the desert biome, and the phytolith discriminant analysis appeared to be more powerful for identifying the desert $\mathrm{C}_{4}$ grassland biome. This difference can be attributed to the fact that phytolith assemblages effectively characterize the grass cover when non-grass taxa are scarce, and indicate the duration or intensity of the water stress to which the grass is subjected. The reliability of phytoliths for characterizing the desert biome is particularly interesting as phytoliths, in contrast to pollen, are well preserved in oxidizing environments.

Both the phytolith discriminant analysis and the pollen biomization method reliably distinguished between tall grass 
savanna and short grass savanna biomes, although the phytolith method correctly assigned a higher percentage of samples of these kinds.

\section{CONCLUSIONS}

The phytolith discriminant analysis procedure presented here accurately identified three $\mathrm{C}_{4}$ grass-dominated biomes that are widespread in West Africa: the desert $\mathrm{C}_{4}$ grassland, the short grass savanna and the tall grass savanna biomes. This was tested by statistical validation and by comparing maps of estimated phytolith biomes and contemporary ecosystem classes.

The success of this first study in defining a method for constructing phytolith biomes highlights the potential value of phytolith analysis in the description of vegetation types. In particular, it is suggested that future studies should be aimed at defining new phytolith discriminant functions for tropical biomes with various tree cover densities (e.g. tree and tall grass savanna, tree and short grass savanna, tropical dry forest, tropical dense forest) or with $\mathrm{C}_{3}$ grass components. The applicability of the calibrated functions to phytolith assemblages from other tropical areas should also be examined. The present study suggests that phytolith data may be used to complement pollen data in attempts to identify tropical biomes according to the following two procedures. First, as in this study, phytolith and pollen biomes can be defined for the same vegetation types and, following Cheddadi et al. (1997), who used a combination of pollen and lake-level data, the assignment of samples to given biomes by the biomization method can be considered to be validated if they are in agreement with the biomes estimated by the phytolith method. Second, a combination of phytolith and pollen data could be used to define new discriminant functions (biomes) using both phytolith indices (Bremond et al., 2005b) and PFT scores as discriminant variables. These developments should improve the reliability of reconstructions of tropical grass-dominated biomes from fossil records, and enhance the effectiveness of model/empirical data comparisons for both past and present systems.

\section{ACKNOWLEDGEMENTS}

This work was supported by the French programs PNEDC (Programme National d'Etudes Dynamique du Climat, INSUCNRS, projects ECHO and Calibration des indices phytolithiques pour l'intégration de la dynamique des biomes herbacés dans la modélisation des végétations passées), ACI Ecologie Quantitative (project RESOLVE), and by the 5th EU PCRDT (EVK2-CT-2002-00153: MOTIF). Pollen data were accessed via the African Pollen Database (http://medias.obs-mip.fr/ apd). We are grateful to Anne-Marie Lézine, who collected the samples from Senegal and Mauritania and made them available to us. Thanks also to Christine Pailles and Jennifer Dickie for language corrections, and to the editor, Ole R. Vetaas, and reviewers for their constructive comments on earlier drafts of this manuscript.

\section{REFERENCES}

Abrantes, F. (2003) A 340,000 year continental climate record from tropical Africa - news from opal phytoliths from the equatorial Atlantic. Earth and Planetary Science Letters, 209, 165-179.

Alexandre, A., Meunier, J.-D., Lézine, A.-M., Vincens, A. \& Schwartz, D. (1997) Phytoliths: indicators of grasslands dynamics during the late Holocene in intertropical Africa. Palaeogeography, Palaeoclimatology, Palaeoecology, 136, 213219.

Barboni, D., Bremond, L. \& Bonnefille, R. (2007) Comparative study of modern phytolith assemblages from inter-tropical Africa. Palaeogeography, Palaeoclimatology, Palaeoecology, 246, 454-470.

Bond, W.J., Woodward, F.I. \& Midgley, G.F. (2005) The global distribution of ecosystems in a world without fire. New Phytologist, 165, 525-537.

Bremond, L., Alexandre, A., Hély, C. \& Guiot, J. (2005a) A phytolith index as a proxy of tree cover density in tropical areas: calibration with leaf area index along a forest-savanna transect in southeastern Cameroon. Global and Planetary Change, 45, 277-293.

Bremond, L., Alexandre, A., Peyron, O. \& Guiot, J. (2005b) Grass water stress estimated from phytoliths in West Africa. Journal of Biogeography, 32, 311-327.

Bremond, L., Alexandre, A., Wooller, M.J., Hély, C., Schäfer, P.A., Majule, A. \& Guiot, J. (2008) Phytolith indices as proxies of grass subfamilies on East African tropical mountains. Global and Planetary Change, 61, 209-224.

Campbell, N.A. (1996) Biology, 4th edn. Benjamin/Cummings, Menlo Park.

Centre de Suivi Ecologique (2000) Annuaire sur l'environnement et les ressources naturelles du Sénégal. Ministère de l'Environnement, République du Sénégal, Centre de Suivi Ecologique, Dakar.

Cheddadi, R., Yu, G., Guiot, J., Harrison, S.P. \& Prentice, I.C. (1997) The climate of Europe 6000 years ago. Climate Dynamics, 13, 1-9.

Cramer, W. (2002) Biome models. Encyclopedia of global environmental change (ed. by T. Munn), pp. 166-171. John Wiley \& Sons, Chichester.

Fredlund, G. \& Tieszen, L.T. (1994) Modern phytolith assemblages from the North American Great Plains. Journal of Biogeography, 21, 321-335.

Goeury, C. \& Guiot, J. (1996) PPPbase software for statistical analysis of paleoecological and palaeoclimatical data. Dendrochronologia, 14, 295-300.

Haxeltine, A. \& Prentice, I.C. (1996) BIOME3: an equilibrium terrestrial biosphere model based on ecophysiological constraints, resource availability, and competition among plant functional type. Global Biogeochemical Cycles, 10, 693-709.

Hély, C., Bremond, L., Alleaume, S., Smith, B., Sykes, M. \& Guiot, J. (2006) Sensitivity of African biomes to changes in the precipitation regime. Global Ecology and Biogeography, 15, 258-270. 
Hsiao, T.C., O’Toole, J.C., Yambo, E.B. \& Turner, N. (1984) Influence of osmotic adjustment on leaf rolling and tissue death in rice. Plant Physiology, 75, 338-341.

Jolly, D., Prentice, I.C., Bonnefille, R., Ballouche, A., Bengo, M., Brenac, P., Buchet, G., Burney, D., Cazet, J., Cheddadi, R., Edorh, T., Elenga, H., Elmoutaki, S., Guiot, J., Laarif, F., Lamb, H., Lezine, A., Maley, J., Mbenza, M., Peyron, O., Reille, M., Reynaud-Farrera, I., Riollet, G., Ritchie, J., Roche, E., Scott, L. \& Ssemmanda, I. (1998) Biome reconstruction from pollen and plant macrofossil data for Africa and the Arabian peninsula at 0 and 6000 years. Journal of Biogeography, 25, 1007-1027.

Kelly, E.F. (1990) Method for extracting opal phytoliths from soil and plant material. Internal Report. Department of Agronomy, Colorado State University, Fort Collins.

Kondo, R., Childs, C. \& Atkinson, I. (1994) Opal phytoliths of New Zealand. Manaaki Whenua Press, Lincoln.

Le Houérou, H.N. (1993) Grasslands of the Sahel. Ecosytems of the world, 8B: natural grassland (ed. by R.T. Coupland), pp. 197-220. Elsevier, Amsterdam.

Leemans, R. \& Cramer, W. (1991) The IIASA database for mean monthly values of temperature, precipitation and cloudiness of a global terrestrial grid. International Institut for Applied Systems Analysis (IIASA), RR-91-18, 61.

Lézine, A.M. (1987) Paléoenvironnements végétaux d'Afrique nord-tropicale depuis 12000 ans B.P. Analyse pollinique de séries sédimentaires continentales (Sénégal-Mauritanie). Volume I: Texte. Volume II: Annexes. Université Aix-Marseille 2, Faculté des Sciences de Luminy, France.

Lézine, A.M., Turon, J.L. \& Buchet, G. (1995) Pollen analyses of Senegal: evolution of the coastal paleoenvironment during the last deglaciation. Journal of Quaternary Science, 10, 95-105.

Loveland, T.R., Reed, B.C., Brown, J.F., Ohlen, D.O., Zhu, Z., Yang, L. \& Merchant, J.W. (2000) Development of a global land cover characteristics database and IGBP DISCover from $1 \mathrm{~km}$ AVHRR data. International Journal of Remote Sensing, 21, 1303-1330.

Lu, H.-Y., Wu, N.-Q., Yang, X.-D., Jiang, H., Liu, K.-b. \& Liu, T.-S. (2006) Phytoliths as quantitative indicators for the reconstruction of past environmental conditions in China I: phytolith-based transfer functions. Quaternary Science Reviews, 25, 945-959.

Madella, M., Alexandre, A., Ball, T. \& ICPN Working Group (2005) International code for phytolith nomenclature 1.0. Annals of Botany, 96, 253-260.

Mulholland, S.C. (1989) Phytoliths shape frequencies in North Dakota grasses: a comparison to general patterns. Journal of Archaeological Science, 16, 489-511.

O’Toole, J.C. \& Cruz, T.R. (1980) Response of leaf water potential, stomatal resistance, and leaf rolling to water stress. Plant Physiology, 65, 428-432.

Olson, J.S. (1994a) Global Ecosystem Framework: definitions. USGS EROS Data Center Internal Report, Sioux Falls, SD.

Olson, J.S. (1994b) Global Ecosystem Framework: translation strategy. USGS EROS Data Center Internal Report, Sioux Falls, SD.
Peyron, O. (1999) Le climat de l'Europe et de l'Afrique au dernier maximum glaciaire et à l'Holocène moyen. Faculté des sciences et techniques de Saint Jérôme, Université de droit et d'économie d'Aix-Marseille III, Marseille.

Peyron, O., Jolly, D., Bonnefille, R., Vincens, A. \& Guiot, J. (2000) Climate of East Africa $6000{ }^{14} \mathrm{C}$ yr BP inferred from pollen data. Quaternary Research, 54, 90-101.

Piperno, D.R. (2006) Phytoliths: a comprehensive guide for archaeologists and paleoecologists. Altamira Press, Lanham.

Prebble, M., Schallenberg, M., Carter, J. \& Shulmeister, J. (2002) An analysis of phytolith assemblages for the quantitative reconstruction of late Quaternary environments of the Lower Taieri Plain, Otago, South Island, New Zealand I. Modern assemblages and transfer functions. Journal of Paleolimnology, 27, 393-413.

Prentice, I.C., Cramer, W., Harrison, S.P., Leemans, R., Monserud, R.A. \& Solomon, A.M. (1992) A global biome model based on plant physiology and dominance, soil properties and climate. Journal of Biogeography, 19, 117-134.

Prentice, I.C., Guiot, J., Huntley, B., Jolly, D. \& Cheddadi, R. (1996) Reconstitution biomes from palaeoecological data: a general method and its application to European data at 0 and 6 ka. Climate Dynamics, 12, 185-194.

Prentice, I.C., Jolly, D. \& Biome6000 participants (2000) MidHolocene and glacial-maximum vegetation geography of the northern continents and Africa. Journal of Biogeography, 27, 507-519.

Sage, R.F., Wedin, D.A. \& Meirong, L. (1999) The biogeography of $\mathrm{C}_{4}$ photosynthesis: patterns and controlling factors. $C_{4}$ plant biology (ed. by R.F. Sage and R.K. Monson), pp. 313-373. Academic Press, Toronto.

Scott, L. (2002) Grassland development under glacial and interglacial conditions in southern Africa: review of pollen, phytolith and isotope evidence. Palaeogeography, Palaeoclimatology, Palaeoecology, 177, 47-57.

Tarasov, P.E., Guiot, J., Cheddadi, R., Andreev, A.A., Bezusko, L.G., Blyakharchuk, T.A., Dorofeyuk, N.I., Filimonova, L.V., Volkova, V.S. \& Zernitskaya, V.P. (1999) Climate in northern Eurasia 6000 years ago reconstructed from pollen data. Earth and Planetary Science Letters, 171, 635-645.

Twiss, P.C., Suess, E. \& Smith, R.M. (1969) Morphological classification of grass phytoliths. Soil Science Society of America Journal, 33, 109-115.

Venables, W.N. \& Ripley, B.D. (2002) Modern applied statistics with $S$, 4th edn. Springer, New York.

Vincens, A., Bremond, L., Brewer, S., Buchet, G. \& Dussouillez, P. (2006) Modern pollen-based biome reconstructions in East Africa expanded to southern Tanzania. Review of Palaeobotany and Palynology, 140, 187-212.

Wallis, L. (2003) An overview of leaf phytolith production patterns in selected northwest Australian flora. Review of Palaeobotany and Palynology, 125, 201-248.

White, F. (1983) The vegetation map of Africa. UNESCO, Paris. Wyk, J. (1979) A general account of the grass cover of Africa. Ecology of grasslands and bamboolands in the world (ed. by M. Numata), pp. 124-132. W. Junk, The Hague. 
BIOSKETCHES

Laurent Bremond is an Assistant Professor of Paleoecology at the Ecole Pratique des Hautes Etudes. He develops methods based on various proxies (phytoliths, cuticles and stable isotopes) to reconstruct modern and past grass distributions in the tropics and mountains.

Anne Alexandre is a CNRS researcher at CEREGE developing the study of phytoliths and oxygen isotope composition of biogenic and low temperature silicates for tropical palaeoenvironments and palaeoclimate reconstructions.

Odile Peyron is a CNRS researcher specializing in the quantitative reconstruction of past climatic parameters from pollen data. Her recent studies have focused on Late glacial and Holocene palaeoclimates in Europe.

Joel Guiot is a CNRS research director at CEREGE. His work is based on vegetation and climate modelling in the past and the impact of global change on vegetation. He is an active member of the international Paleoclimate Modelling Intercomparison Project (PMIPII) and president of the French Scientific Committee on long-term global climatic change (EVE).

Editor: Ole Vetaas 